\title{
Diponegoro War History in Total War Perspective in Supporting Strategies the National Defense
}

\author{
Akhiyar Meideri, Lukman Yudho Prakoso \\ Prodi Strategi Perang Semesta, Fakultas Strategi Pertahanan, Universitas Pertahanan Indonesia \\ DOI: https://dx.doi.org/10.47772/IJRISS.2021.5414
}

\begin{abstract}
The background of this paper recounts the superiority of the guerrilla war strategy carried out by Prince Diponegoro in his war against the Dutch East Indies army. Prince Diponegoro and his troops won this battle, because in addition to his war strategy, this war was also supported by various resources in the Yogyakarta and surrounding areas. The purpose of this research is to emulate the spirit of fighting spirit and nationalism of Pangeran Diponegoro in order to defend his people and maintain the integrity and sovereignty of his country. In addition, this study aims to further enhance the spirit of defending the State for the Indonesian people with the support of current technological developments. This research method is a qualitative approach, the type of research is history, especially the roles and figures of past struggles whose names are still remembered in the present and in the future. The results showed that the guerrilla warfare that was applied by PangeranDiponegoro had its existence today and in the future, which could still be emulated. However, it is necessary to modernize the equipment of the Indonesian armed forces, as well as improve the guerrilla warfare strategy, so that it does not take place conventionally in accordance with the increasing development of the latest technology. The existence of state defense forces needs to be maintained, but the material needs to deepen the understanding of state defense including material on religion, ideology, and the latest technological developments.
\end{abstract}

Keywords : TotalWar, Diponegoro, Strategy, Defense

\section{INTRODUCTION}

$\mathrm{T}$ he Diponegoro War, also known as The Java War, was a grueling war for the Dutch and drained a lot of resources, including troops and money or funding which caused the colonial government to experience a financial crisis. In this war, he was led by Prince Diponegoro, one of the figures who became a national hero of Indonesia.

Prince Diponegoro is remembered for his services and persistence in fighting against the Dutch East Indies government in 1825-1830 or the war which was recorded as the battle with the greatest casualties in Indonesian history. Apart from his persistence, PangeranDiponegoro had an extraordinary war strategy by gathering strength from civil society, and taking advantage of his charisma, so that Prince Diponegoro succeeded in convincing the people to jointly fight against the colonialism of the Dutch East Indies government. With this strategy, Prince Diponegoro was able to fight and repel colonialism by the Dutch East Indies government.
There are several excellences of Prince Diponegoro, religiously. PangeranDiponegoro was a leader who had high integrity because he was very religious, honest, assertive and brave. (Purworejo. 24, n.d.)Prince Diponegoro also has a nationalist spirit. who are high and always pro people. This was reflected in his anti-Dutch attitude, starting with the increasing influence of the Dutch in matters of the kingdom, the oppression of the people was increasing as well. Even the Dutch government leased an unlimited amount of land to private Dutch entrepreneurs to be used as plantations. As a result, the land that can be cultivated by the people for agriculture is getting narrower. Even roads are rented out. Every person passing the road must pay taxes (Mansur, 2005). The condition, it triggered the anger of Prince Diponegoro, causing the DiponegoroWar or Java War from 1825-1830. The Diponegoro War made the Dutch East Indies government almost bankrupt in terms of war funding because of a combination of religious and socio-economic motives, exacerbated by Prince Diponegoro's guerrilla war tactics moving from one region to another. The war tactics carried out by Prince Diponegoro's troops made it difficult for the Dutch to quell the rebellion. Prince Diponegoro's war tactics, which were always scattered and moved around the place, then attacked while the enemy was off guard, known as Guerrilla war tactics. (Y, 2015)

Guerrilla War (Fundamentals of Guerilla Warfare) according to General Abdul Haris (AH) Nasution in his book "Guerilla Principles and Defense of the Republic of Indonesia in the Past and in the Future", says "The basic idea of guerrilla warfare is to use all strength (resources) to defeat the stronger enemy ". In the book, AH.Nasutionsaid "Guerrilla War is the Total People's War, where the main condition for its success lies in the solidarity and mutual trust between the military and the people." (A. H. Nasution, 1980)

Guerrilla warfare by utilizing Indonesia's mountainous and forested natural conditions is also capable of supporting and adjusting the defense strategy of the Republic of Indonesia. According to AndiWidjajanto, Indonesia's defense strategy in his book entitled "Evolution of Indonesian Defense Doctrine", states: "Indonesia's defense doctrine has evolved into 5 (five) periods, namely the period of the war for independence (1945-1949), RIS (1949-1950).), internal war (1950-1959), guided democracy (1959-1967), and the New Order (1967-1998). From this evolutionary analysis, it shows that the basic character of Indonesia's defense doctrine is the 
doctrine of total defense. The main strategy is to mobilize all national resources, active defensive titles, unified operations degrees, layered defense conceptions, territorial defense titles, and guerrilla warfare titles. Due to past war experiences, the concept of defense relies heavily on ground defense. A new strategy must be born from a review that is relevant to the present. "(Widjajanto, 2005)The idea of Indonesia's defense strategy according to AndiWidjajanto is in line with the Law of the Republic of Indonesia Number 3 of 2002 concerning State Defense, in Article 1 point 2 emphasizes: "The national defense system is a comprehensive defense system that involves all citizens, territories and citizens of the Republic of Indonesia. other national resources, as well as being prepared early by the government and implemented in a total, integrated, directed, and continuous manner to uphold state sovereignty, territorial integrity, and the safety of the entire nation from all threats. Furthermore, in point 4, it emphasizes that the management of national defense is all activities at the strategic and policy level which include planning, implementation, supervision and control of national defense. "

According of Article 1 point 2 and 4 of the State Defense Law is also supported by the sound of Article 9 paragraph (1) Every citizen has the right and obligation to participate in efforts to defend the state which are manifested in the administration of State defense; (2) The participation of citizens in efforts to defend the state, as meant in paragraph (1), shall be carried out through a) citizenship education; b) compulsory basic military training; c) voluntary or compulsory service as a soldier in the Indonesian National Army; and d) dedication in accordance with the profession.

Defense Theory, the implementation of state defense is aimed at safeguarding and protecting the sovereignty of the country, territorial integrity and the safety of the entire nation. State defense for the Indonesian nation is arranged in a total defense system, not aggressive and not expansive in order to protect national interests. (K. P. R. Indonesia, 2015) Solving problems related to and affecting national defense is carried out by prioritizing diplomacy which is strengthened by modern military forces. The national defense system is total which involves all citizens, territories and other national resources, and is prepared early by the government and is carried out in a total, integrated, directed and continuous manner to uphold state sovereignty, territorial integrity, and the safety of the entire nation from all threats (Article 1 paragraph 2 of the Law on State Defense).

Carl von Clausewitz or better known as Clausewitz was an officer of the Prussian Army (now Germany) who was brilliant because his thoughts on the philosophy of war and military, were still adhered to and are still very relevant today. In his well-known book entitled "ON WAR", Clausewitz describes philosophy, politics, civil-military relations, strategy, and even operations for waging war. We may agree that at the operational and tactical level, of course a lot has to be adapted to the current situation and conditions in the world marked by advances in the technology of the main weapons and information technology (Clausewitz, 2002)

The theory of Total War was coined by JS Prabowo (a Minister of Defense of the Republic of Indonesia), in his book entitled "Principles of Thought about Total War" (Prabowo, 2009) Prabowo conveyed that the concept of defense in effect in Indonesia is based on the concept of "defense the people of the total "which is called a doctrine that was born from the history of the nation. According to him, if the State is forced to engage in war, then the war that will be carried out is "total people's war" or "the concept of the total people's war". That is the Indonesian doctrine so far, born from our history that every citizen has the right and duty to participate in defending the State. Maybe our infrastructure can be destroyed, but I believe that it is impossible for Indonesia to be occupied by other nations because all the people will become a component of the country's defense (Minds, 2019)

This Total War Theory was coined by Great General Nasutionas outlined in his book entitled "Guerilla Principles." (A. Nasution, 1954) The war of this century is the war of the total people. Guerrilla War is a war of the little / the weak against the big / the strong. Guerrilla warfare cannot by itself bring about the final victory, guerrilla warfare is only for the blood of the enemy. The final victory can only be with a regular army in an ordinary war, because only such an army can go on the offensive and only the offensive can conquer the enemy. Guerrilla warfare is usually an ideological war, guerrilla warfare is a total people's war. But guerrilla warfare does not mean that all the people are fighting. Guerrilla warfare should not be arbitrary. Guerrilla based in the people. The people help, care for and hide the guerrillas, and investigate for their needs. The guerrilla arsenal is the enemy's arsenal. Summing up guerrilla war strategy and tactics. The main characteristic of guerrilla warfare is the people who help, sufficient geographical space and the existence of a long war. Total people's war requires total leadership and not only at the national peak, but also in the lowest guerrilla areas. Anti-guerrilla warfare must lead to separating the guerrillas from the people of origin, and therefore must give priority to political, psychological and economic movements. Guerrillas must be fought with their own weapons, offensive activities, mobile and flexible capabilities.

Andi Widjajanto said national defense is one of the functions of government, which is carried out through a total national defense system involving all citizens, territories and national resources as well as national infrastructure and implemented in a total, integrated, directed and sustainable manner. State defense is carried out through efforts to build and foster the ability, deterrence of the state and nation, and to overcome any threats. State defense is managed by the government and prepared early with a state defense system by utilizing national resources and infrastructure as regulated by law (National Defense Implementation Policy 2015, 2015) 
From this evolutionary analysis, it shows that the basic character of Indonesia's defense doctrine is the doctrine of total defense. The main strategy is to mobilize all national resources, active defensive titles, unified operations degrees, layered defense conceptions, territorial defense titles, and guerrilla warfare titles. Due to past war experiences, the concept of defense relies heavily on ground defense. A new strategy must be born from a review that is relevant to the present.

Widjajanto said the State Defense Doctrine is the basic principles that provide direction for the management of defense resources to achieve national security goals. These basic principles consist of six contents of defense doctrine, namely: the nation's perspective on war, the components of the country involved in the war, the control of war, the mechanism of accountability, the strategy of war and the termination of war.

The six doctrinal contents need to be organized into several consistent strata from the political, military, to professional levels. At the political level, the political principles of the doctrine contain several matters relating to the duty of the armed forces to face armed military threats. At the military level, doctrine answers more questions about how military force will be used to deal with threats. The use of military force may accommodate the need for early prevention strategies so that small-scale wars do not spread.

Referring to the description above, in this paper the writer will put forward 2 (two) problems, namely first, how is the relevance of Prince Diponegoro's war strategy in the Past and its contribution in the Present and Future, in supporting the country's defense strategy from the perspective of total war. ? Second, what is the current readiness of the Indonesian people in supporting the national defense strategy through empowering all citizens of the country?

\section{METHODE}

The research approach used is a qualitative approach, as stated by Bogdan and Taylor (in Lexy J. Moleong) that a qualitative approach is a research procedure that produces descriptive data in the form of written or spoken words from people and observable behavior. The qualitative approach is directed at the individual's background holistically (intact). In this case, it is not permissible to isolate individuals or organizations into variables or hypotheses, but it is necessary to view them as part of something wholeness (Moleong, 2009).

The type of research used is historical biography or it can also be called historical interpretation. At this stage, the author uses the theory of "Big People" and the theory of Sociology "Status and Roles". While historiography is the process of compiling historical facts and various sources that have been selected in the form of historical writing (Sulasman, 2014)

\section{DISCUSSION}

Prince Diponegoro is the prince of the Yogyakarta Sultanate. Born on November 11, 1185. His real name was Raden Mas Mustahar which was later changed to Raden Mas Antawijaya as he was aged according to the tradition of the palace. Raden Mas Antawijaya is the son of Raden Mas Suraja or who later reigned with the title Sultan HB III. The father actually wanted Raden Mas Antawijaya to become the crown prince. However, the wish of Sultan HB III was politely rejected. (P, 2021a)Because his mother was not the wife of the king's consort, Raden Mas Antawijaya felt that he did not have the right to sit on the throne of Yogyakarta, even though Raden Mas Antawijaya was the oldest son. Besides that, Raden Mas also did not really like the luxurious life in the palace. Sultan HB III died in 1814 and was succeeded by Raden Mas IbnuJarot, son of the empress's wife. At that time, Raden Mas IbnuJarot or who would later hold the title Sultan HB IV was still 10 years old.

The influence of the Dutch on the palace was getting stronger when the palace was unstable. Because Sultan HB IV was still young. Fed up with the situation, Raden Mas Antawijaya decided to leave the palace and then lived in his grandmother's residence in the Tegalrejo area, Yogyakarta. This is where Raden Mas Antawijaya alias Prince Diponegoro's resistance to the Dutch started.

Sagimun in his book "PahlawanDipanegaraBerjuang (1957) explains, there are several reasons why Prince Diponegoro tried to fight colonialism by the Dutch East Indies government, namely the Dutch were increasingly interfering in the internal affairs of the Yogyakarta Palace. Due to Dutch influence, the tax burden borne by the people became very heavy. The Dutch plan to build a railroad that passed through the residence of his grandmother made Prince Diponegoro steadfastly resisted. (P, 2021b)

On the other hand, according to the history quoted by the author from the free article, he explained, "In May 1825 the Dutch East Indies government, which was about to build a road from Yogyakarta to Magelang via Muntilan, changed its plan. The road construction route was diverted through Tegalrejo, which incidentally is the residence of Prince Diponegoro. Prince Diponegoro's fury towards the Dutch East Indies began when the colonial government staked or pegged the burial ground of his ancestors to be used as a road. Later, Prince Diponegoro replaced the land stakes with spears. "(Republika.Co.id, n.d.) The stakes made the community uneasy. Community unrest was exacerbated by high taxes, disrespect for customs and overexploitation from the Dutch. Finally, a dispute ensued and spread to a war that lasted for five years (Kompas.com, 2021)

Because of his actions, the Dutch East Indies Government considered Prince Diponegoro to have rebelled and rebelled. Finally, the Dutch East Indies troops visited Tegalrejo and surrounded the residence of Prince Diponegoro. However, Prince Diponegoro was managed to escape and was rescued by his followers, then stayed temporarily in 
DesaDeksoKulonprogo. During his escape, Prince Diponegoro found a cave, namely Selarong Cave, which is located in KentolanLor Hamlet, GuwosariPajanganBantul. Prince Diponegoro finally made the cave to gather and form a power base.

In his struggle against the Dutch East Indies colonial troops, Prince Diponegoro received the full support of the people, clerics, and the aristocracy. Apart from Prince Diponegoro, a figure who always aroused the enthusiasm and courage of the fighters was Kiai Mojo, who always emphasized that "The Diponegoro War or the Java War was a Jihad that all Muslims had to do. The aim was to fight the suffering and misery caused by the arbitrariness and injustice of the Dutch East Indies government (Republika.Co.id, 2016)

This war took place in parts of the island of Java, with the location of Yogyakarta on the south coast to the border of Banyumas in the west, and Magelang in the north.

Diponegoro's resistance received a wide response from various parties, both from the rural people and the aristocratic groups, officials, scholars, and other community leaders. Support for Prince Diponegoro can also be proven from the extensive map of the battle area. If you pay attention to the battlefield spread widely, not only in the central area of Yogyakarta - Surakarta, but also in Central and East Java, such as Kedu, Banyumas, Pekalongan, Semarang, Pati, Bojonegoro, Madiun, Kediri and the surrounding areas.

The war ended when Prince Diponegoro was tricked into the negotiating table in Magelang in May 1830, because the negotiations planned by the Dutch were only used as a trap to arrest him. Prince Diponegoro was arrested and exiled to Manado, and then transferred to Makassar until his death on January 8, 1855. (Sarjo, 1990)

Prince Diponegoro's war against colonialism and oppression of the people by the Dutch East Indies government, as well as expelling the Dutch colonial army, was a war which took a long time (1825-1830) and the war ended with Prince Diponegoro trapping the negotiations planned by the Dutch. The war that was classified as long (the Diponegoro war or the Java war) was identical to the war of the Acehnese people against colonialism and oppression carried out by the Dutch East Indies colonial army, which lasted from 1873-1910.

Responding to the Diponegoro War in fighting and expelling the Dutch East Indies colonial troops who would control the entire territory of Yogyakarta at that time, and the war which took so long and claimed many lives both from the Indonesian people and the Dutch East Indies colonial troops, reflected that in the future military forces The Army must better prepare and modernize its defense equipment in accordance with current developments in science and technology. This was conveyed by Brigadier General of the Army D. Doetoyo, in a bulletin entitled "SatitiBaktiCakti Army Research and Development Service".
In the Bulletin, D. Doetoyo said: "The rapid development of science and technology has driven globalization and gave birth to a new world, namely a world as if it is borderless. Along with the advancement of science and technology, new threats and challenges that have never been imagined by humans have developed before. (Doetoyo, 2018) These challenges and threats, if not fully addressed and responded to in a complete manner, are thought to threaten the implementation of national development and disrupt the achievement of national goals as mandated in the Preamble to the Constitution. 1945. In the current perspective, the form of future threats will be more mixed or better known as "Hybrid Thread". In other words, the threats that are currently developing are not only from the birth of new types of weapons as a result of the rapid development of military technology, but have metamorphosed into a hybrid threat that can threaten not only the sovereignty of a State but more than that threatening human existence. itself. Therefore, the Indonesian State must build its national defense as early as possible so that guarantees of the sovereignty of the Republic of Indonesia can be realized. The existence of a country must be supported by strong defense so that the Indonesian nation is not undermined both from within and from outside. This large country of Indonesia has had a long decline in the development of its defense equipment.

From the results of research through a historical approach that the struggle of Prince Diponegoro (1825-1830) in fighting and expelling the Dutch colonial army in Java and its surroundings, as well as the long Aceh War (1873-1910) against the colonial rule of the Dutch East Indies government, shows that the two The war is appreciated as a hard and persistent effort and is supported by the strategies possessed by Indonesia's national heroes, to be emulated by the current military leaders (especially the Indonesian Army) as their great struggle to liberate the nation and the Republic of Indonesia from the grip of the colonialists. . So that in the future, to maintain and defend the sovereignty of the Republic of Indonesia, it needs to be supported by the modernization of the Indonesia Armed Forces'sdefense system, especially the Army, and it is necessary to foster and enhance the spirit of nationalism and patriotism of all Indonesian people along with the development of science and technology (Science and Technology) today or a world without borders ( borderless).

The Relevance of Prince Diponegoro's War Strategy in the Past and Its Contribution in the Present and in the Future in Supporting the National Defense Strategy from a Total War Perspective.

In essence, the war strategy carried out by Prince Diponegoro was a guerrilla war strategy by utilizing the natural conditions in the Yogyakarta region and its surroundings, which are mountainous, valley and forested. This condition provided an advantage for Prince Diponegoro's troops so that it was right to carry out a guerrilla war by the troops led by Prince Diponegoro. 
In this guerrilla war, Prince Diponegoro was supported by many scholars and other figures, especially the full support of the surrounding people who were already angry with the Dutch East Indies colonial troops who carried out extortion and oppression for the Indonesian people, especially those in the Yogyakarta and surrounding areas.

Guerrilla warfare, which is fully supported by the people of Yogyakarta and its surroundings, is a Total War strategy as conveyed by General AH. Nasution in his theory is the Theory of Total War, which contains the main points of the guerrilla.

Based on a book written by the Great General AH.Nasution, entitled "Guerrilla Principles" published in 1954, contained several guerrilla issues, including: The War of the Century was the Total People's War; The war effort is not just an effort of the army, but and has instead become the effort of the people of all sectors of their life. (A. H. Nasution, 1980) The war that is now no longer a war between soldiers and soldiers alone, is no longer just a military war. But now it is the people who are at war, the people as a whole. The war was turbulent as a whole, although the final decision was determined by the defeat and victory of the two armed forces opposite. So the science of war is not only a special science of war with its strategy, tactics and logistics, but also military politics, politics, psychology, and economics. The battlefield is no longer just military, but also completely political and economic.

Guerrilla War is a war of the little / the weak against the big / the strong; Guerrilla warfare is not because we adhere to a guerrilla "ideology", but because we are obliged, because we have been unable to organize a modern organized force equal to the enemy. So our guerrillas are only at the level of tiring the enemy, not yet able to destroy them even if part by piece. Guerrilla warfare cannot by itself bring about the final victory, guerrilla warfare is only for the blood of the enemy. The final victory can only be with a regular army in an ordinary war, because only such an army can go on the offensive and only the offensive can conquer the enemy. The defensive cannot defeat the enemy, only the offensive can. The defensive is just temporarily setting up and looking forward to going offensive at some point. Strategic guerrilla warfare is only defensive. Victory in war is possible only by the offensive, by an offensive by a well-organized soldier, by an equal army.

Guerrilla wars are usually ideological wars. Guerrilla war is a total people's war; Guerrilla warriors are not just weapons bearers, but are bearers of ideology. The oppressed people, the colonized people, the people who are persecuted by the occupation, clench their fists to get rid of the occupation, the oppressor and the cruel inhabitants. Ideology and the spirit of independence become a source of strength and ability to start a war against a strong and regular enemy with all his armies. The actions of the guerrilla should not only prioritize battles, but must also prioritize psychological and socioeconomic conditions with pro-propaganda movements, non-cooperative politics, scorched earth politics, and so on.

Guerrilla warfare does not mean that all the people fight; The people are the joints of the guerrilla. Guerrilla warfare is a people's war, guerrilla warfare is born and grows on the days of the struggling people, guerrilla fighting with the help, maintenance and protection of the people as well. Guerrillas are true people's warriors.

Guerrilla warfare cannot be arbitrary; The guerrillas must also be disciplined, also have to organize, also have to train, also have to learn combat tactics, also have to have designs and calculations. The guerrilla must be guerrilla against the enemy, so that he remains confused and confused about the circumstances and the aims of the guerrilla, but must be organized and disciplined towards the leader himself.

Guerrilla based in the people. The people help, care for and hide the guerrilla, as well as investigate for their needs; The guerrilla arsenal is the enemy's arsenal. Weapons and ammunition are extremely important and extremely difficult in a guerrilla war. As a child, it can be understood how important it is to save energy and save bullets.

The guerrilla strategy carried out by Prince Diponegoro in his efforts against the Dutch East Indies colonialism was a strategy that was weakening not destroying. In addition, in the guerrilla strategy, efforts were made to expand the scope of attacks. The goal is to expand the attack so that the opponent can spread out his troops as well, so that his strength is divided and easy to attack. Non-cooperation and scorched earth were also used in the face of the Dutch. The purpose of non-cooperation is to refuse to cooperate with the enemy.

The role of the people is very big in guerrilla warfare because the people are a source of logistics and assistance for the guerrilla forces. The people and the DIY government are expected to support the struggle of the guerrilla forces and refuse to cooperate with the Dutch in any case. The guerrilla strategy which was scorched earth was to destroy vital objects that could be exploited by the Dutch. Vital objects that were important to the Dutch could be roads and airstrips that could connect Dutch troops inside the city and outside the city as well as outside the Yogyakarta area, as well as other sources of vital value to the Dutch troops.

From most of these guerrilla points and strengths, it can be seen that the main objective of the guerrilla warfare carried out by Prince Diponegoro in the past, and in the present and in the future, is primarily to defend the sovereignty of the Republic of Indonesia. This is identical as stated in the Decree of the Minister of Defense of the Republic of Indonesia Number: KEP / 1255 / M / XII / 2015. In this decision, it was emphasized that "National Defense is essentially all defense efforts that are total in nature, characterized by democracy, totality, and territory. The national defense system in facing military threats places the 
INDONESIA ARMED FORCES as the main component supported by the reserve and supporting components. "(National Defense Policy, 2016)

The national defense policy aims: Realizing a state defense capable of facing threats. Realizing a state defense capable of handling maritime area security, land security and aerospace security.Realizing state defense that is able to play a role in creating world peace.Creating a strong, independent and competitive defense industry.Realizing awareness of State defense for Indonesian citizens."'(National Defense Policy 2016, 2016)

The great fighting spirit of Prince Diponegoro to fight and expel the Dutch colonial army was inseparable from the great nationalist and religious spirit of Prince Diponegoro and his troops (the people of Yogyakarta and its surroundings), so that the struggle yielded satisfying results.

The great unity of the principles of nationality and religious principles from Prince Diponegoro and his people, and the Great General AH.Nasution and his troops, all of which constitute a relationship between civilians and the military in the politics and government system.

The Indonesian military, according to its history, grew naturally in a long journey to seize and defend the independence of the nation and state before finally being formed into the National army. In the course of its history of struggle, the Indonesian military has never fought alone but has always been in synergy with the people. Based on these historical facts, the identity of the Indonesian military is referred to as the People's Army and warrior. His identity as a people's army and warrior army continues to develop and form an institutionalized and crystallized belief in the hearts and minds of every member of the Indonesian military so as to give birth to the doctrine of State defense which is then formed in a State defense system called the Total People's Security Defense System (National Total Defense). The core strength of National Total Defense is the unity of the military / Indonesia Armed Forces with all levels of the Indonesian people. (K. P. RI, 2019)

This total State Defense and Security System has the characteristics of democracy, totality and territory. The populist characteristic means that the defense orientation is served by and for the benefit of all the people. The total characteristic means that all national resources are utilized for defense efforts. Territorial characteristics are the titles of defense forces that are spread throughout the territory of the Unitary State of the Republic of Indonesia, in accordance with geographic conditions as a unit of defense. (D. Defense, 2008)

For Indonesia, the implementation of state defense and security is not solely aimed at war, but also for realizing peace, guaranteeing the integrity of the Unitary State of the Republic of Indonesia, securing national interests and ensuring the implementation of national development. An effective national defense and security system is defense and security capable of providing a safe and peaceful atmosphere where people's lives run normally, and relations with other countries both in the region and outside the region take place in harmony and mutual respect.

The Current Readiness of the Indonesian People in Supporting the National Defense Strategy through Empowering the People of the Total. In order to build and shape the character of the Indonesian people in supporting the national defense strategy, including the Ministry of Defense organizing and increasing the empowerment of the total people, through "State Defense Education".

State defense awareness has been mandated in Article 27 paragraph (3) of the 1945 Constitution of the Republic of Indonesia, which reads "Every citizen has the right and obligation to participate in efforts to defend the State." Furthermore, in Article 30 paragraph (1) of the 1945 Constitution of the Republic of Indonesia, it reads "Every citizen has the right and obligation to participate in the defense and security of the State".

Further elaboration on State defense is contained in Law of the Republic of Indonesia Number 3 of 2002 concerning State Defense, Article 9 states that "State Defense is the attitude and behavior of citizens who are animated by their love for the Unitary State of the Republic of Indonesia based on Pancasila and the 1945 Constitution, in ensuring the survival of the nation and the State. "(National Defense, 2002) These attitudes and behaviors do not just appear to be the consciousness of every citizen from birth, so they need to be nurtured from an early age and continuously maintained and developed through fostering awareness of State defense.

The essence of fostering awareness of State defense is an effort to build the character of the Indonesian nation that has a spirit of nationalism and patriotism and has a strong national resilience to ensure the upholding of the Republic of Indonesia, which is based on Pancasila and the 1945 Constitution and the maintenance of the implementation of national development in achieving its goals. national. (KP RI, 2017)

The development of state defense awareness aims to realize and improve the defense capabilities of the Republic of Indonesia through the implementation of the State defense system in land, sea and air forces by realizing the development of reserve and supporting components; Development and implementation of the concept of defense of large islands; The development of the posture of the Indonesian Armed Forces which has the capability of strategic deterrence and high mobility to be projected inside and outside the jurisdiction of the Unitary State of the Republic of Indonesia in the context of enforcing sovereignty and protecting national interests; Revitalizing the defense industry as a producer of defense and security equipment that is advanced, strong, independent and competitive to meet the needs of national defense; Increasing international cooperation in the field of defense and involvement in world 
peace missions under the auspices of the United Nations (UN) and other international institutions in the context of participating in maintaining world order and peace; Increased military defense capability carried out by ministries outside the field of defense, institutions, and local governments by optimizing the utilization of national resources for the benefit of national defense (Presidential Regulation, General Policy for National Defense).

Observing the objectives of the aforementioned state defense awareness building, it is inseparable from the theory of State Defense conveyed by AndiWidjajanto, regarding the 2045 Regional Strength Strategic Plan with 3 (three) trajectories of the Republic of Indonesia 2045 State Defense Posture, namely Indonesia's defense politics tends to transform into a State. democratic which will enable the emergence of a strong civilian capacity to form a professional military force; then the stability of the international system 2050 shows that Indonesia must develop a war power that allows Indonesia to play a counterbalancing role; The last global economic crisis tends to hamper the development of the defense posture in 2045. However, the strategic gaps that have emerged in the global arms market can be exploited by Indonesia to develop its own defense force.

The independence of the defense industry of a nation will be qualified if it is supported by sophisticated technology. In order to encourage Indonesia's defense independence, our defense technology industry must be able to move further, far, far from where we are today.

For the sake of realizing the creation of Indonesia's defense independence, a mature strategic plan and scheme is needed so that our defense technology industry develops rapidly. The defense industry development strategy for the advancement, strength and independence of Indonesia's defense, the formulation of which must be based on defense technology. Defense technology can logically be used to formulate the independence of defense facilities in an effort to tackle threats both from within and from abroad (Widiyanto, 2016)

In the plan to develop the defense equipment posture and defense technology industry, the government links the plan to develop the defense equipment posture with the defense industry independence achievement program. In the 2020-2024 phase, to support the ideal military posture, the industry must be able to significantly and be able to produce advanced technology through international cooperation. (Karim, 2014) In the end, the government realizes that the ideal defense force posture, which is expected, will not be achieved without an independent defense industry, having high technology capabilities to collaborate internationally and having the ability to develop sustainable production. In addition, the ultimate goal of developing the defense industry is not only to meet the needs of domestic defense equipment, but also to break through the export market to compete internationally, and to make the defense industrial sector as one of the main drivers of economic growth (Samego, 2001).

Apart from the need for an independent defense industry to support the ideal Indonesian military posture, it is also necessary to foster and increase the capacity of the reserve components (Komcad), especially Indonesian citizens, and natural resources, especially in valley forests, which can be found in the archipelago. .

The Reserve Component in the form of human resources, especially Indonesian citizens, is contained in Law Number 23 of 2019 concerning Management of National Resources for State Defense. In its consideration, it states "that every citizen has the right and obligation to participate in the defense and security of the State as mandated in the 1945 Constitution." Furthermore, "The national defense system is total involving all national resources which are prepared early by the Government and implemented in a total, integrated, directed and sustainable manner to uphold state sovereignty, maintain territorial integrity and the safety of the entire nation from all forms of threats".

In addition to the reserve component in the form of Indonesian citizens who are involved in the defense and security of the State, another component is the natural resources owned by Indonesia, which are so numerous and varied, including forest resources. The existence of forests in Indonesian territory is very supportive in warfare, such as in the war of Prince Diponegoro who used the forest which was full of offerings in carrying out his guerrilla war against and repelling Dutch colonial rule. Forests, according to Kartasubrata, explained that "forest, land and water as natural resources can provide the maximum direct benefit to the community, so that the welfare of the community around the forest can be further improved without neglecting the sustainability of the forest itself. Therefore, activities are needed to develop communities around forests by involving them in various forestry activities (Kartasubrata, 1986).

In this millennial era, war no longer utilizes natural resources, especially forests (for example the Prince Diponegoro war), but wars in this millennial era utilize highlevel technology. One example is that the application of IT has transformed the analogue world into a digital world which is marked by the increasing level of connectivity through inter and between net lines. Science is so easily accessible to anyone that in many ways the millennial generation can quickly access information that can enrich their thinking, attitude and action, which can affect in responding to the problems faced, as well as in the implementation of the understanding of State defense. Therefore there are several basic elements of State Defense, including Love for the Fatherland, Awareness of the Nation and the State, Believing in Pancasila as the State Ideology, Willing to Sacrifice for the Nation and State, and having the initial ability to Defend the State (ZainalAbidin, 2014) 
In this case, defending the State is not only seen as a state duty, but also as an honor and trust given by the State to every citizen who should be proud of and carried out with full awareness, responsibility, full of spirit and willing to sacrifice for the sake of devotion to the motherland. nation and state.

\section{CONCLUSION}

Prince Diponegoro's war strategy by applying a guerrilla war strategy in the past, is still relevant for its existence in the future, in order to maintain and maintain the integrity of the Unitary State of the Republic of Indonesia. However, the guerrilla war strategy needs to be further improved in quality in various fields, in the sense that it is not only to tire or be fooled by enemy soldiers but to be able to scorch enemy soldiers so that the war does not last so long.In order to support the national defense strategy through empowering the total people, what needs to be prepared is the readiness of the Indonesian people to be obliged to take part in the "State Defense" education program, seriously.

Current and future guerrilla war tactics or strategies, it is necessary to take brilliant innovative steps along with the increasing development of science and technology which is considered borderless so that military leaders need to think about innovative and brilliant steps with using extraordinary mobility and a brilliant strategy, in order to defend and improve the defense strategy of the Republic of Indonesia from the efforts of other countries to weaken and destroy the sovereignty of the Unitary State of the Republic of Indonesia, both in the sea, land and air areas.

\section{REFERENCES}

[1]. Clausewitz, C. Von. (2002). On War. Princeton University Press.

[2]. Doetoyo, D. (2018). Peran Litbang INDONESIA ARMED FORCES AD: Dalam Mendukung Transformasi INDONESIA ARMED FORCES AD Guna Mewujudkan Kemandirian Alutsista Modern. Buletin Dinas Penelitian dan Pengembangan Angkatan Darat Satiti Bakti Cakti

[3]. Dipua, A., Hermawan, R., Puspitawati, D., Harahap, N., Rizanny, D., \& Prakoso, L. Y. (2020). An Analysis of The South China Sea Conflict: Indonesia's Perspectives, Contexts and Recomendations. PalArch's Journal of Archaeology of Egypt/Egyptology, 17(4), 976-990.

[4]. Guntur Eko Saputro, L. Y. (2021). Implementation of Economic Policies Facing Covid 19 in Supporting Nonmilitary Defense. International Journal of Social Science And Human Research, 634-642.

[5]. Indonesia, K. P. R. (2015). Buku Putih Pertahanan Indonesia (Cetakan Ke). Kementerian Pertahanan RI.

[6]. Hermawan, T., Prakoso, L. Y., \& Sianturi, D. (2020). Strategi Pertahanan Laut dalam Analisa Dampak dan Upaya Pemerintah Mengamankan ALur Laut Kepulauan Indonesia. Strategi Pertahanan Laut, 6(3), 273-296.

[7]. Kurniawan, C., Widyarto, S., \& Prakoso, L. Y. (2018) Implementasi Struktur Birokrasi Strategi Pertahanan Laut Menghadapi Ancaman di Perairan Provinsi Sulawesi Tenggara. Strategi Pertahanan Laut, 4(1), 1-18.

[8]. Kebijakan Penyelenggaraan Pertahanan Negara tahun 2015, Pub. L. No. Nomor 19 Tahun 2015 (2015).

[9]. Karim, S. (2014). Membangun Kemandirian Industri Pertahanan Indonesia. Kepustakaan Populer Gramedia.

[10]. Kartasubrata, J. (1986). Partisipasi Rakyat dalam Pengelolaan dan Pemanfaatan Hutan di Jawa. Institut Pertanian Bogor.
[11]. Kompas.com. (2021). Mengenang Pangeran Diponegoro dan Sejarah Perjuangannya. https://www.kompas.com/tren/read/2021/01/08/180500665/menge nang-pangeran-diponegoro-dan-sejarah-perjuangannya?page=all.

[12]. Mansur, H. (2005). Seri Pangeran Diponegoro. Mandar Madju.

[13]. Minds, M. for. (2019). Pengamat: Konsep Perang Rakyat Semesta Prabowo Bukan tentang Wajib Militer. Https://Www.Dw.Com/Id/Pengamat-Konsep-Perang-RakyatSemesta-Prabowo-Bukan-Tentang-Wajib-Militer/a-51210848.

[14]. Moleong, L. J. (2009). Metodologi Penelitian Kualitatif. Remaja Rosdakarya.

[15]. Nasution, A. (1954). Pokok-Pokok Gerilya. CV. Pembimbing.

[16]. Nasution, A. H. (1980). Pokok-Pokok Gerilya: Dan Pertahanan Republik Indonesia di Masa Lalu dan Yang Akan Datang. Angkasa.

[17]. P, Y. (2021a). Kronologi Sejarah Perang Diponegoro: Sebab, Tokoh, Akhir, \& Dampak. https://tirto.id/kronologi-sejarah-perangdiponegoro-sebab-tokoh-akhir-dampak-f9ZJ.

[18]. P, Y. (2021b). Kronologi Sejarah Perang Diponegoro: Sebab, Tokoh, Akhir, \& Dampak. https://tirto.id/kronologi-sejarah-perangdiponegoro-sebab-tokoh-akhir-dampak-f9ZJ

[19]. Pertahanan, D. (2008). Buku Putih Pertahanan Indonesia 2008. Kementerian Pertahanan RI.

[20]. Pertahanan Negara, Pub. L. No. Nomor 3 Tahun 2002 (2002).

[21]. Kebijakan Pertahanan Negara Tahun 2016, Pub. L. No. KEP/1255/M/XII/2015 (2016).

[22]. Prabowo, J. (2009). Pokok-Pokok Pemikiran tentang Perang Semesta. Pusat Pengkajian dan Strategi Nasional.

[23]. Purworejo.24. (n.d.). Keteladanan Pangeran Diponegoro, Pahlawan Nasional dan Pemimpin Religius. https://www.purworejo24.com/2019/09/keteladanan-pangerandiponegoro-pahlawan-nasional-dan-pemimpin-religius/.

[24]. Republika.Co.id. (n.d.). Perang Jawa dan Jihad Pangeran Diponegoro. https://www.republika.co.id/berita/oizth9313/perangjawa-dan-jihad-pangeran-diponegoro.

[25]. Republika.Co.id. (2016). Perang Jawa dan Jihad Pangeran Diponegoro. https://www.republika.co.id/berita/oizth9313/perangjawa-dan-jihad-pangeran-diponegoro.

[26]. RI, K. P. (2017). Bela Negara Dalam Perspektif Strategi dan Kebijakan Pertahanan Negara. Puskom Publik Kemhan.

[27]. RI, K. P. (2019). Eksistensi INDONESIA ARMED FORCES Dalam Menghadapi Ancaman Militer dan Nirmiliter Multidimensional Di Era Mileneal. Biro Humas Sekjen Kemhan.

[28]. Kebijakan Pertahanan Negara, Pub. L. No. Nomor: $\mathrm{KEP} / 1255 / \mathrm{M} / \mathrm{XII} / 2015$ (2016).

[29]. Samego, I. (2001). Sistem Pertahanan-Keamanan Negara: Analisis Potensi dan Problem. The Habibie Center.

[30]. Sarjo, D. (1990). Kepemimpinan Pangeran Diponegoro Dalam Perspektif Sejarah. Makalah

[31]. Suhirwan, \& Prakoso, L. Y. (2019a). Defense strategy at sea handling of Transnational Organized Crime (TNOC) in Nunukan Indonesia's national sea border. IOP Conference Series: Earth and Environmental Science, 339, 12043. https://doi.org/10.1088/17551315/339/1/012043

[32]. Sulasman. (2014). Metodologi Penelitian Sejarah. Pustaka Setia.

[33]. Widiyanto, J. I. dan B. (2016). Kebijakan Offset Dalam Membangun Kemandirian Pertahanan Negara. Pertahanan, 6(2).

[34]. Widjajanto, A. (2005). Evolusi Doktrin Pertahanan Indonesia (I. N. Bakti (ed.)).

[35]. Y, S. dan T. (2015). Strategi Politik Pakubuwana VI Melawan Kolonial Belanda Tahun 1823 - 1830. CANDI, 12(2).

[36]. Zainal Abidin, D. (2014). Buku Ajar Pendidikan Bela Negara. UPN Veteran. 